\title{
Introduction. Morphing Bodies: Strategies of Embodiment in Contemporary US Cultural Practices
}

\section{Nathalie Massip}

\section{CpenEdition}

\section{Journals}

\section{Electronic version}

URL: https://journals.openedition.org/transatlantica/9293

DOI: 10.4000/transatlantica.9293

ISSN: $1765-2766$

\section{Publisher}

Association française d'Etudes Américaines (AFEA)

\section{Electronic reference}

Nathalie Massip, "Introduction. Morphing Bodies: Strategies of Embodiment in Contemporary US

Cultural Practices", Transatlantica [Online], 1 | 2017, Online since 19 November 2018, connection on 25 May 2021. URL: http://journals.openedition.org/transatlantica/9293 ; DOI: https://doi.org/10.4000/ transatlantica.9293

This text was automatically generated on 25 May 2021

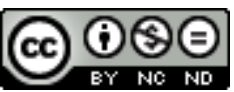

Transatlantica - Revue d'études américaines est mise à disposition selon les termes de la licence Creative Commons Attribution - Pas d'Utilisation Commerciale - Pas de Modification 4.0 International. 


\title{
Introduction. Morphing Bodies: Strategies of Embodiment in Contemporary US Cultural Practices
}

\author{
Nathalie Massip
}

1 For a long time, transgenderism was depicted as a personal, marginal phenomenon. It was studied from either a medical or a psychological perspective, and the literature devoted to the topic "framed being trans as an individual psychopathological deviation from social norms of healthy gender expression [...]" (Stryker, 2017, 2). In the 1960s and 1970s, the Diagnostic and Statistical Manual of Mental Disorders referred to transgender identity as "sexual deviations" (Drescher, 2014, 141).

2 The representation of transgender characters in novels or films, when it happened at all, tended to emphasize this idea of "deviation," if not perversion. Norman Bates, Psycho's protagonist, is a gender-troubled psychopath and serial killer (Bloch, 1959), as is The Silence of the Lambs' Buffalo Bill character (Harris, 1988). Occasionally, transgender persons made for colorful characters in novels or movies as was the case of ex-football player Roberta Muldoon in John Irving's The World According to Garp (1978) or the Lady Chablis in John Berendt's Midnight in the Garden of Good and Evil (1994). The Lady, a real-life drag performer born Benjamin Edward Knox, was a fixture of Savannah's clubbing scene until her death in 2016. A less clichéd and a rare instance of a more balanced depiction was the protagonist of Boys Don't Cry (1999). The movie was based on the true story of Brandon Teena, who was born a girl yet started identifying as male during adolescence and was the victim of a hateful crime in a small town in Nebraska in 1993. Because his "sexual identity crisis" did not turn Brandon into a freak, the movie was applauded for its evenhanded portrayal of the main character's gender bending, therefore signaling an evolution in terms of representation of transgender people.

3 The trend accelerated in the 2000s, as movies and TV programs featured more transgender characters. At the same time, transgender celebrities became more visible, such as former soldier Chelsea Manning or retired athlete Caitlyn Jenner. In May 2014, 
Orange Is the New Black's trans actress Laverne Cox was on the cover of Time magazine acknowledging this evolution and hailing "The Transgender Tipping Point." (Steinmetz, 2014). The issue put forward that the Diagnostic and Statistical Manual of Mental Disorders had stopped referring to transgenderism as "disorder" since 2013, yet had substituted it with "gender dysphoria." In addition, it depicted transgenderism as "America's Next Civil Rights Frontier."

Despite this increasing visibility, the very concept of transgenderism remained a riddle for a majority of people and had to be explained. It could not be summed up as a questioning of one's identity only. The body, the physical envelope, was a crucial aspect of the question: "For many trans people, the body they were born in is a suffocating costume they are unable to take off" (Steinmetz, 2014). Body and identity do not match, thereby creating a discomfort. As the Latin origin of the prefix "trans" suggests, it is necessary to some people to go beyond this body, to cross over the gender and physical attributes they were given at birth. Taking off this "suffocating costume" implies modifying this body, transforming it so that it would better suit their identity.

5 Bodies are so malleable that there is a wide range of ways to transform them. In fact, bodies keep evolving as they grow up, grow old, work out, diet, gain weight, suffer from diseases... While physiotherapy may help repair a damaged or wounded body, prosthetics can make a maimed body whole again. As far as transgenderism is concerned, bodies can be made to morph through hormone therapy and surgery. While the possibilities of transformations seem endless, some bodies may be more flexible than others, and even this flexibility has its limits. A recent Atlantic article on children and adolescents and transgenderism warned against the potentially "irreversible" effects of "the physical interventions of hormones or surgery" (Singal, 2018, 94). The article brought forward examples of individuals who had suffered from a "temporary" gender dysphoria as teenagers and, after having "transitioned", had later sought to "detransition," that is to revert to the gender they were assigned at birth (Singal, 94; 96-107). The article and the examples it featured are a reminder that the flexibility of bodies can be stretched only so far.

Beyond physical bodies, the same assertion could be made regarding the American body politic. The notion of a "body politic" was first theorized in the twelfth century. In Policraticus, John of Salisbury described the republic as "a sort of body which is animated [...]" He went on to compare each branch of society to a body part:

The position of the head in the republic is occupied [...] by a prince [...]. The place of the heart is occupied by the senate [...]. The duties of the ears, eyes and mouth are claimed by the judges and governors of provinces. The hands coincide with officials and soldiers. Those who always assist the prince are comparable to the flanks. Treasurers and record keepers [...] resemble the shape of the stomach and intestines [...]. Furthermore, the feet coincide with peasants perpetually bound to the soil [...] who erect, sustain and move forward the mass of the whole body. (John of Salisbury)

As in a body, each part of society has its function; an injury to one may result in damages to the whole structure. Unity is created through reciprocity and collaboration between the different parts, and "there can be no faithful and firm coherence where there is not a tenacious unity of wills and a virtual joining together of souls themselves" (John of Salisbury). This cohesiveness is meant to ensure and protect the common good. 
7 Since the election of Donald Trump in November 2016, the President's numerous assaults on the various parts of the American body politic have tested the endurance of American institutions. His attacks on the free press, his use of social media to bully opponents and those who dare to criticize him, his contempt for the independence of the judiciary are but a few examples of the "head" of the republic injuring the various parts of its body.

Just like transforming a body may seriously-if not irreversibly-impair it, leaving scars that even the passage of time will not erase, abusing long-standing institutions may harm American democracy permanently:

Political norms that are the bulwark of our democracy cannot be easily repaired once damaged, even if Trump's most dangerous policies are stopped. Nor can white supremacist, anti-immigrant, and nativist rhetoric be swiftly sidelined once condoned by the U.S. president. (Acemoglu).

Since their creation in the late eighteenth century, U.S. institutions have proved to be malleable and adaptable. Yet, as with bodies, their flexibility can be stretched only so far: "if democratic institutions are truly strong and alert against threats, these attacks can be resisted. But the performance of U.S. checks and balances so far gives no comfort." (Acemoglu) The impact of the current "head's" various blows to the body parts could be deep and long-lasting. It remains to be seen whether the President's radical remaking of the American body politic will have permanently altered, if not damaged it.

Flexibility and transformation are at the heart of the articles that compose this issue of Transatlantica titled "Morphing Bodies: Strategies of Embodiment in Contemporary US Cultural Practices." Goodman's article pinpoints the flexibility of multifaceted literary forms derived from photography, and the visual strategies used by Native American authors to counter the "vanishing Indian" narrative. Through her analysis of two photo-texts, Leslie Silko's Storyteller and Joy Harjo's Crazy Brave, Goodman demonstrates how the association of photographs and texts-i.e., taking bodies out of the original photographs and placing them alongside texts-allows both authors to transform not only the medium itself but also the very identities of the individuals on the photos. Drawing on Gerald Vizenor's concept of "survivance," Goodman shows how, in asserting Native Americans' physical presence as proof of endurance, these multigenre forms enable Silko and Harjo to reclaim their indigenous history.

Studying New York artists from the New American Avant-Garde, Emeline Jouve focuses on the use of technology as a means to theatricalize actors' bodies. Just as Goodman shows how photo-texts are flexible and multifaceted, Jouve highlights the hybridity that results from the use of technology on stage, which contributes to a renewal of traditional theatre. Through examples of shows and performances by three artists and companies, Jouve shows how technology transforms, distorts, augments, diminishes, fragments or deconstructs bodies to the point of engendering new identities. While it sometimes creates monsters and cyborgs, therefore potentially acting as an alienating tool, technology mainly enhances bodies, as it is used not to weaken the centrality of the performer but to foreground the complexity of humans.

11 Performance is also at the heart of Claude Chastagner's article. Chastagner focuses on the dancing bodies of Pharrell Williams' 2013 "Happy" video, a 24-hour video featuring a wide range of people using their bodies and facial expressions to convey the emotion the song is about. The originality and success of the video has prompted a large number 
of tribute videos throughout the world, and Chastagner endeavors to find out whether there is a typically American body language to express happiness. Ultimately, the dancers' literal pursuit of happiness begs the question of their freedom as the song and its call for happiness seem to convey an injunction to be happy more than a genuine expression of happiness.

Finally, Katherine Hankins, Andy Walter and Traci Dahl show that faith-based programs may potentially change cities while also transforming the very participants who embody the love that is at the root of these programs. Through their actions, the "intentional neighbors" of Mission Year, a Christian community-development organization and the authors' case study, located in Atlanta, Georgia, become agents of urban social change. The study reveals that, in the process, participants' own perceptions of social (in) justice evolve and are reshaped by their experience in the Mission Year program and as a result of their exchanges with their neighbors.

All the articles contained in this issue show the flexibility and malleability of individual and collective bodies in America. The motions and transformations they undergo are indicative of the most significant social, political, artistic and cultural trends in the United States today.

\section{BIBLIOGRAPHY}

ACEMOGLU, Daron, "It's Too Early to Celebrate the Survival of American Democracy." Foreign Policy, Nov. 15, 2017, https://foreignpolicy.com/2017/11/15/its-too-early-to-celebrate-thesurvival-of-american-democracy/. Accessed 1 Sept. 2018.

BERENDT, John, Midnight in the Garden of Good and Evil. New York, Random House, 1994.

BLOCH, Robert, Psycho. New York, Simon and Schuster, 1959.

Boys Don't Cry (Fox Searchlight Pictures, Kimberly Peirce, 1999).

DRESCHER, Jack, “Gender Identity Diagnoses: History and Controversies.” Gender Dysphoria and Disorders of Sex Development, edited by B. Kreukels, et al., New York, Springer, 2014.

HARRIS, Thomas, The Silence of the Lambs. New York, St Martin's Press, 1988.

IRVING, John, The World According to Garp. Boston, E.P. Dutton, 1978.

JOHN OF SALISBURY, Policraticus: Of the Frivolities of Courtiers and the Footprints of Philosophers, edited and translated by Cary J. Nederman, https://archive.org/stream/

JohnOfSalisburyPolicraticusJohnOfSalisbury/John \%20of \%20Salisbury_ \%20Policraticus \%20\%20John \%20of \%20Salisbury_djvu.txt._Accessed 1 Sept. 2018.

SINGAL, Jesse, "Your Child Says She's Trans. She Wants Hormones and Surgery. She's 13." The Atlantic, July/August 2018, p. 88-107.

STEINMETZ, Katy, “The Transgender Tipping Point. America's Next Civil Rights Frontier.” Time, June 9, 2014. 
STRYKER, Susan, Transgender History: The Roots of Today's Revolution. 2008. New York, Seal Press, 2017.

VIZENOR, Gerald, editor. Survivance: Narratives of native Presence. Lincoln (NE) and London, University of Nebraska Press, 2008.

\section{AUTHOR}

NATHALIE MASSIP

Université Côte d'Azur 